\title{
Gizli Demokrasi: Temsili Demokrasi Krizi ve Doğrudan Demokrasi Talebi Arasındaki İlişkiye Yönelik Bir Görüş
}

\author{
Stealth Democracy: A View on the Relationship Between the Crisis of \\ Representative Democracy and Demand for Direct Democracy \\ Yavuz Selim ALKAN ${ }^{1}$
}

Geliş tarihi: 28.05.2018, Kabul tarihi: 24.08.2018, Basım tarihi: 30.09.2018

\section{Özet}

Bu çalışma ${ }^{2}$, John R. Hibbing ve Elizabeth Theiss-Morse tarafindan geliştirilen "gizli demokrasi" kavramı üzerine kısa bir inceleme sunmaktadır. Gizli demokrasi, demokrasi üzerine akademik literatürde yaygın ve baskın konumda olan (i) temsili demokrasinin bir kriz içerisinde olduğu, ve bu nedenle de, (ii) özellikle doğrudan katılıma yönelik giderek artan oranda bir talep olduğu iddiasına yönelik bir görüştür ${ }^{3}$. Hibbing ve Theiss-Morse, temsili demokrasinin bir kriz içerisinde olduğunu kabul etmektedirler. Bununla birlikte, akademideki yaygin görüşün aksine, temsili demokrasi krizinin aşılmasının politik karar alma süreçlerine daha az doğrudan vatandaş katılımı ve siyasa oluşturma sürecinde daha çok uzman görüşüne yer verme ile sağlanabileceğini savunmaktadırlar. Gizli demokrasi anlayışını da böylece daha az katılımcı fakat daha çok elitist bir temel üzerine inşa etmektedirler. Bu bağlamda, bu çalışmanın amacı, bilgimiz dahilinde, Türkçe akademik literatürde henüz üzerine yazılmış kapsamlı bir çalışma yer almayan gizli demokrasi kavramının, kendini alternatifi olarak sunduğu yaklaşımlara odaklanarak, kısa bir incelemesini ve sonraki

\footnotetext{
1 Akdeniz Üniversitesi, İİBF Siyaset Bilimi ve Kamu Yönetimi Bölümü, Dr. Öğr. Üyesi, https:/ / orcid.org/0000-0002-5211-5809

yavuzselimalkan@akdeniz.edu.tr

2 Bu çalışmanın erken bir taslağı, 1-4 Kasım 2017 tarihleri arasında Isparta Süleyman Demirel Üniversitesinde düzenlenen, "KAYFOR 15: Dijital Çağda Kamu Yönetimi ve Politikaları" ana temalı uluslararası kongrede sözlü bildiri olarak sunulmuştur. Bildirinin tam metni ise bahsedilen konferans tam metin bildiri kitabı da dahil olmak üzere hiçbir yerde yayımlanmamıştır. Bu çalışma, bahsedilen kısa taslak bildiri özetinin; yeni, geliştirilmiş ve zenginleştirilmiş bir makale halidir. Özet bildiri metni için bkz. http://sempozyum.sdu.edu.tr/kayfor15/tr/images/Kayfor15BookofAbstracts.pdf, erişim tarihi 4 Mayis 2018.

Yazar, makalenin son şeklini almasındaki değerli katkıları için dergi editörü ve (kimliği saklı tutulmuş) üç hakeme teşekkür eder ve makaleyle ilgili her türlü akademik sorumluluğun bizzat kendisine ait olduğunu kabul eder.

3 Gizli demokrasi için makalenin başlığında "görüş" ibaresinin kullanılmış olması bilinçli bir tercihtir. Makalenin ilgili bölümlerinde de belirtildiği gibi, bu tercihin yapılmasının ilk nedeni gizli demokrasinin bir kuram ya da yaklaşım olarak kabul edilip edilemeyeceğinin tartışmalı olmasıdır. ABD'de yapılan, ulusal kamuoyu araştırması ve odak grup çalışmalarından elde edilen bulgulara dayalı bir durum tespitinden yola çıkarak bir demokrasi anlayışı veya kuramına ulaşmak sorunlu ve tartışmalıdır. İkinci neden de, çalışmada da sunulmaya çalışıldığ üzere, Hibbing ve Morse'un demokrasi üzerine oluşturdukları görüş ve önerilerinin aslında "yeni”" veya "orijinal” olmadığıdır. Bu iki sebeple bu çalısmada, gizli demokrasinin akademik literatürdeki yerini belirlemek için "görüş" ibaresi kullanılmıştır.
} 
akademik çalışmalara esas oluşturması amacıyla temel ve kısa bir eleştirisini sunmaktır.

Anahtar Kelimeler: Demokrasi, giz̨li demokrasi, temsili demokrasi, doğrudan demokrasi, müzakereci demokrasi.

\begin{abstract}
This study provides a brief examination of the concept of "stealth democracy" developed by John R. Hibbing and Elizabeth Theiss-Morse. Stealth democracy is a view on the prevalent and dominant perspective in the scholarly literature on democracy that (i) representative democracy is in a crisis, and thus (ii) there is a growing demand for direct democracy. Hibbing and Theiss-Morse acknowledge that representative democracy is in a crisis. However, contrary to the prevalent view in academia, they maintain that the crisis of representative democracy is overcome by allowing less direct citizen involvement for political decision making processes, but more expert opinion in the policy formation process. They therefore build their understanding of stealth democracy on the basis of a less participatory but a more elitist perspective. In this sense, the aim of this study is to examine the concept of stealth democracy, to the best of our knowledge, on which there has been no comprehensive study in the Turkish-written scholarly literature by focusing on the perspectives to which it provided itself as an alternative and to provide a brief critique of the concept with the aim of building a foundation for further research.
\end{abstract}

Keywords: Democracy, stealth democracy, representative democracy, direct democracy, deliberative democracy.

\title{
Giriş
}

Demokrasi söz konusu olduğunda, yaklaşık elli yıldır, sadece teorik ve normatif çalışmalar anlamında değil, pratik ve ampirik düzeyde de, gelişmiş ülkelerin yerleşik (liberal) demokratik sistemleri üzerine yapılan pek çok akademik çalışmada bir saptamanın ön plana çıktığı görülmektedir. Bu saptama, temsili demokrasinin bir kriz içerisinde olduğu ve bu krizin temsili demokrasiye alternatif başka demokrasi anlayış ve yöntemlerine yönelerek aşılması gerektiğidir. Bu çerçevede, özellikle temsili demokrasinin süreçleri, karar alma mekanizmaları ve kurumlarına yönelik artan memnuniyetsizlik ve güvensizlik üzerine eleştirel bir akademik literatür şekillenmiştir. Bu literatür, hem teorik/normatif hem de ampirik perspektiften, birbirinden farkl idealleri ve değerleri gerçekleştirme hedefi doğrultusunda — örn. meşruiyet veya eşitlik gibi — temsili demokrasi krizine yönelik en temel alternatif çare olarak politik süreç ve karar alma mekanizmalarına katılımın arttırılmasını sunmuştur.

Bu anlamda; doğrudan demokrasi, e-demokrasi, katılımcı demokrasi, güçlü demokrasi, müzakereci demokrasi, agonistik demokrasi vb. gibi farklı isimler altında şekillenen ve birbirlerinden temelde oldukça farklı teorik varsayım ve ilkeler benimseyen yaklaşımlar, temsili demokrasinin bahsedilen 
krizinin aşılmasına yönelik birer alternatif çare olarak sunulmaya başlanmışlardır. Bu yaklaşımların tümünün (liberal demokrasi ve/veya) temsili demokrasiye yönelik eleştirel tutumlarının ontolojik temellerinin, teorik ve normatif açıdan bu iki demokrasi anlayışını "içeriden" mi yoksa "dışarıdan" mı eleştirdikleri sorusuna verilen cevapların veya her birinin "katılım" ve onun boyutları noktasındaki görüşlerinin farklı olduğu aşikardır. Ancak tüm farklılıklarına rağmen öne çıkan bu alternatif demokrasi anlayış ve türlerinin vurgu yaptığı ortak temanın katılım olması ve de "eğer bir 'temsili' demokrasi krizi varsa, çözüm de 'doğrudan' katılım olmalıdır” yönündeki düşünce, özellikle konuya ilişkin ampirik çalışmalara odaklanan akademik literatürde tüm bu farklı yaklaşımların "doğrudan demokrasi”" talebi ve gerekliliği teması altında birleştirilmesine yol açmıştır. Başka bir deyişle, doğrudan demokrasi, bahsedilen tüm bu farklı demokrasi anlayışları arasında demokratik karar alma sürecine doğrudan ve aracısız katılımı temel aldığ1 için temsili demokrasiye karşı en belirgin alternatiflerden biri olarak ön plana çıkmıştır ${ }^{4}$.

Temsili demokrasinin bir kriz içinde olduğu ve yerleşik (liberal) demokratik toplumlarda, artan oranda bir doğrudan demokrasi talebi olduğu yönündeki yukarıda bahsedilen ve bu çalışma çerçevesinde de aşağıda detayları sunulacak çalışmalar, akademik literatürde oldukça yaygın ve de baskın bir konumdadır. Öyle ki bu yaygın anlayışa zit görüşler sunan çalışmalar çok az sayıdadır. Bu az sayıdaki çalışmalardan en dikkat çekenlerinden biri ise özellikle politik davranışlar üzerine önemli çalışmaları

\footnotetext{
${ }^{4}$ Şunu belirtmek gerekir ki bu çalısma; (liberal ve/veya) temsili demokrasiye yönelik yukarıda bahsedilen eleştirel demokrasi yaklaşımlarının tümünün "doğrudan demokrasi" genellemesinin altına yerleştirilmiş olmasını, sadece temsili demokrasi krizi ve doğrudan demokrasi talebi arasındaki ilişkiye yönelik, özellikle ampirik çalışmalara odaklanan akademik literatürde oluşmuş, genel bir kanı veya görüş olarak sunar. Bu durum, bu görüşün benimsendiği veya doğru bulunduğu anlamına gelmemektedir. Elbette agonistik veya müzakereci demokrasi anlayışlarının "liberal demokrasinin sınırları dışına çıktığını" veya "müzakerenin doğası gereği katılımcı" olduğunu savunan görüşler mevcuttur. Ancak katılımcı demokrasi, müzakereci demokrasi, iletişimsel demokrasi gibi birçok demokrasi modeli, aslında özünde liberal demokrasi ve onun genel kabul görmüş katılım formu olan temsili demokrasinin birer alternatifi olarak değil — ya da başka bir deyişle onu "dışarıdan" değil "içeriden" eleştiren — aksine onu düzeltmeye, geliştirmeye yönelik eleştirilerle ortaya çıkmışlardır. Bu bakımdan bu modellerin en azından ilk ortaya çıkış formlarının temsili demokrasiyi tamamen yadsıdığı ve yerine doğrudan demokrasiyi getirmeyi hedeflediği söylenemez. Başka bir deyişle, "liberal demokrasi eleştirisi" ve "temsili demokrasi eleştirisi" her zaman aynı şeyleri ifade etmese de denebilir ki, bahsedilen bu alternatif demokrasi yaklaşımları, temelde liberal demokrasinin kurumlarını reddetmez; onların dönüştürülmesini, iyileştirilmesini ve daha demokratik hale getirilmesini talep eder. Özetle, makalede incelenen ve tartışlan akademik literatür bu şekilde sunduğundan, bu çalışma boyunca teknik sebeplerle "doğrudan demokrasi" ile kastedilen şey, "temsili" demokrasi krizine yönelik en önemli alternatif olarak "katılımın" sunulması olacaktır. Yoksa "katılım"; müzakereci olabileceği gibi, amaçlanan demokratik iyileştirmenin aksine; popülizm veya "plebisiter demokrasi" ile de bağdaştırılan bir kavrama dönüşebilir.
} 
olan ve önde gelen siyaset bilimcilerden ikisi olan John R. Hibbing ve Elizabeth Theiss-Morse tarafından gerçekleştirilmiş olanıdır. Hibbing ve Theiss-Morse (2002), yeni bir demokrasi türü olduğunu savunduklar1 giə̌li demokrasi anlayışını ortaya atmışlardır. Hibbing ve Theiss-Morse, Amerika Birleşik Devletleri örneğindeki ampirik çalışmalarının sonuçlarından yola çıarak temsili demokrasinin krizi ve çözüm önerileriyle ilgili olarak birtakım teorik varsayımlara ulaşmışlardır. İkili, çalışmalarında temsili demokrasinin bir krizde olduğunu kabul etmektedirler. Ancak özetle krize yönelik çarenin, yayg1n görüşün aksine, karar alma süreçlerine daha çok doğrudan katıllım yoluyla değil, politik karar alma süreçlerine daha az doğrudan katılım ancak daha çok uzman görüşüne yer verme ile bulunabileceğine inanmaktadırlar. Elitist perspektiften izler taşıyan bu yeni kavramla Hibbing ve Theiss-Morse, hem doğrudan demokrasi talebine yönelik bahsedilen akademideki yaygın görüşe karşı1 neredeyse tek zit görüşü ortaya koymuş hem de bu zit anlayış üzerinden yeni bir demokrasi "türü" ortaya atmışlardır.

Bu çerçevede bu çalışmanın ilk kısmında temsili demokrasi krizi ve artan doğrudan demokrasi talebi üzerine baskın ve yaygın konumda olan özellikle ampirik temelli görüşler/çalışmalar sunulup incelenecektir. İkinci kısımda ise bu görüşlere zıt olarak geliştirilen en belirgin görüşlerden biri olan gizli demokrasinin en temel varsayımları ve ilkeleri sunularak incelenecektir. Çalışmanın sonuç kısmı ise bir "değerlendirme" bölümü olacak şekilde oluşturulmuştur. $\mathrm{Bu}$ bölümde gizli demokrasi anlayışı üzerine eleştirel bir perspektiften genel bir değerlendirme sunulmaya çalışlacaktır. Ancak çalışmanın asıl amacı Türkçe akademik literatüre gizli demokrasi bir incelemesini kazandırmak ve bahsedilen eleştirel kısım başka bir çalışmanın konusu olabilecek genişlikte olduğundan, ilgili kısım kısa tutularak sadece sonraki çalışmalara yön verecek temel ve kısa görüşlere yer verilecektir.

\section{Temsili Demokrasinin Krizi ve Karar Alma Süreçlerine Doğrudan Katılım Talebi}

Demokrasinin bilinen ilk formu Antik Yunan'daki haliyle doğrudan demokrasidir. Ancak buna karşın temsili demokrasi, zaman içerisinde artan nüfus ve genişleyen coğrafyalar nedeniyle (Knopff, 1998:688; Pitkin, 2004:336), özellikle de 20. yüzyıldan beri, çağdaş demokrasilerde en etkili ve yaygın karar alma mekanizması halini almıştır. Ancak temsil, seçimler, oy verme davranışları, siyasal partiler vb. gibi genel olarak demokrasinin kurumsal boyutuna odaklanan temsili demokrasiye karşı akademik literatürde, özellikle son elli yılda, demokrasinin değer boyutuna odaklanan teorik ve normatif perspektiften ciddi eleştiriler yöneltilmeye başlanmıştır. Oldukça kapsamlı ve çok boyutlu olan bu eleştirel yaklaşımlar kısaca temsili demokrasinin sürekli kendini tekrarlayan bir elit yönetimi oluşturduğunu, bunun da kitleleri karar alma süreçlerinde pasifleştirdiğini (Pitkin, 2004:340) savunmaktadır. Bununla birlikte, temsilcilerin vatandaşların tercih ve 
perspektiflerini yansıtamadığı ve bu nedenle de vatandaşların kendi adlarına alınan kararlarda çok az etkili olduğu bir politik sistemin ve karar alma mekanizmasının oluştuğunu (Smith ve Wales, 2000:51) ileri sürmektedirler. Bu durumun da vatandaşların siyaset ve demokrasi noktasinda yeteneksiz ve bilgisiz olarak nitelendirildiği; demokrasilerin hiyerarşik ve teknokratik bir yapıya büründüğü; politik karar almanın sadece teknokratik uzmanların, organize olmuş çıarların ve seçilmiş temsilcilerin işi olduğu bir politik ortam yarattığ iddia edilmektedir (Hartz-Karp ve Briand, 2009:167).

Eleştirilerin odaklandığ1 ve özellikle müzakereci demokrasiyi savunanların vurgu yaptığı husus ise, birey tercihlerinin oy verme ve seçimler yoluyla adeta "sadece kafa sayma" yoluyla alınmasının yetersiz olduğudur (Saward, 2003:121). Başka bir deyişle, demokrasinin sadece verili veya sabit tercihlerin yine sadece oy merkezli bir bakış açısıyla toplanmasından ibaret olmadığıdır (Chambers, 2003:308; Weale, 2007:82). Neticede bu teorik ve normatif temelli eleştirel yaklaşımlar, sayılan nedenlerle temsili demokrasinin meşruiyet, eşit katılım, devlet tarafsızlı̆̆, şeffaflık vb. noktasında bir kriz içerisinde olduğunu savunurlar. Bu krizin de ancak karar alma mekanizmalarına bireylerin daha çok ve doğrudan katılımının arttırılması yoluyla aşlacağını savunmaktadırlar. Bu öneriyi tamamlayıcı şekilde, özellikle müzakereci demokrasi savunucuları tarafindan dile getirildiği haliyle, oy vermeyi önceleyen fikir ve irade oluşumunun iletişimsel süreçlerine vurgu yapan konuşma (tartsşma)-merkezli bir demokrasi anlayışının, oy-merkezli temsili demokrasi anlayışının yerini alması önerilmektedir. Bunu da, farklı dünya görüşleri ve iyi hayat anlayışlarına sahip bireylerin müzakere aracılığıyla birbirlerini tanıyarak ve farklılıklarını öğrenerek bir arada barış içinde yaşamalarının koşulu olarak saymaktadırlar. (Chambers 2003:308; bk. Dryzek, 1990; Fishkin, 1991; Habermas, 1996; Bohman, 1998, Cooke, 2017).

Özetle son elli ylldır demokrasi üzerine olan teorik ve normatif temelli tartışmalar temsili demokrasi eleştirisi ve daha fazla katılımcı bir demokratik yönetim tarzı bulma üzerine odaklanmaktadır (Dalton vd., 2001:141). Temsili demokrasinin kusurlu yanlarına ve yaşadığ krize yapılan vurgu; doğrudan demokrasi üzerine yapılan çalışmalarda, siyasi partilere olan kamusal güvensizlik ve düşük katılım üzerinde etkileyici bir "rönesansa" yol açmıştır (Dalton vd., 2001:141). Teorik ve normatif çalışmaların argümanlarını destekleyici görüşler ise ampirik çalışmalardan gelmiştir. Doğrudan demokrasiye yönelik artan akademik ilgi, kendisini ampirik çalışmalar anlamında da göstermiştir. Pek çok sayıda ampirik çalışma, yukarıda bahsedilen teorik ve normatif çalısmaları destekler yönde alan çalışmalarına imza atmıştır. Bu çalışmaların amacı, pratikte hem temsili demokrasinin tüm süreç, kurum ve aktörlerine olan güven ve ilginin azalıp azalmadığını hem de vatandaşların politik süreçlere daha artan oranda katılım yapmak isteyip istemediklerini saptamaya çalışmak olmuştur (Barber, 
1984; Butler ve Ranney, 1994; Gallagher ve Uleri, 1996; Gerret, 1997; Norris, 1999; Gray ve Caul, 2000; Pharr vd., 2000; Dalton, 2004; Dalton ve Scarrow: 2004; Donovan ve Karp, 2006; Alonso vd., 2011, Altman, 2011; Morel ve Qvortrup, 2017). Aşağıda bahsedilecek olan gizli demokrasi anlayışı da, bir ampirik çalışmadan türemiş ve akademik literatürdeki yukarıda bahsedilen ampirik çalışmalara odaklanarak alternatif görüşler sunmaya çalışıştır. Bu nedenle çalışsmanın bu kısmında, temsili demokrasi memnuniyetsizliği ve doğrudan demokrasi talebi artışıla ilgili ampirik çalışmalara daha detaylı yer vermek yerinde olacaktır.

Yukarıda bahsedilen temsili demokrasi ve doğrudan demokrasi ilişkisi, özellikle pek çok sayıda ampirik çalışma vasıtasıyla iki soru üzerinden incelenmiştir: (i) temsili demokrasi süreç ve kurumlarına olan güven ve memnuniyet azalmış mıdır ve/veya neden azalmıştır, ve (ii) temsili demokrasiye alternatif olması gereken demokratik karar alma yöntemi nedir? "Eğer bir temsili demokrasi krizi yaşanıyorsa, çare doğal olarak doğrudan katılım araçlarına yönelmek olmalıdır" düşüncesi, kaçınılmaz olarak ikinci sorunun cevabı üzerinde akademik literatürde bir önyargiya yol açmıştır. Aslında ikinci soru ile amaçlanan şey artan doğrudan demokrasi/katılım taleplerini ampirik olarak da ortaya koymaya çalışmaktır. Ayrıca amaç, bu artan talebin nedenlerini ampirik verilerden genel teorik varsayımlara ulaşmak yoluyla saptamaya çalışmak olmuştur. Bu bağlamda, çok ciddi sayılda akademik çalışma, temsili demokrasinin kurum ve süreçlerine karşı - özellikle de siyasal partilere ve siyasal temsilcilere karşı - artan oranda bir eleştirel yaklaşım, güvensizlik ve memnuniyetsizlik olduğunu ortaya koymuştur (bk. Norris, 1999; Pharr vd., 2000; Dalton, 2004, 2008; Invernizzi-Accetti ve Wolkenstein, 2017). Bu sonuçlara paralel olarak da, bireylerin karar alma süreçlerine daha aktif doğrudan katılımı talep ettiklerini ortaya çıkaran yine çok ciddi sayıda akademik çalışma yapılmıştır (bk. Dalton vd., 2001; Inglehart ve Welzel, 2005; Donovan ve Karp, 2006; Bowler vd, 2007; Gherghina, 2017).

$\mathrm{Bu}$ çalışmalar arasında akademik literatürde oldukça sıklıkla referans verilen ve doğrudan demokrasi taleplerinin nedenlerini anlamaya yönelik iki farklı açıklama sunan Russell J. Dalton ( vd., 2001; 2004)'un çalışmaları önemli bir yer tutmaktadır. Dalton'a göre artan doğrudan demokrasi talebi Yeni Politika/Bilissel Hareketlilik ve Politik Memnuniyetsizlik teorileriyle aç1klanabilir.

Yeni Politika/ Bilisssel Hareketlilik teorisine göre, çağdaş toplumların değişen değerleri ve politik yetenekleri, onların siyaseti nasıl gördükleri noktasında büyük değişiklikler getirmektedir (Dalton vd., 2001:145). Modernleşme çeşitli yeni postmateryalist politik ilgileri beslemekte ve vatandaşların politik rolü hakkındaki beklentilerde değişime yol açmaktadır (Inglehart, 1977, 1990; Dalton vd., 2001:146). Burada postmateryalist değerlerle kastedilen 
şey, insanların yeni değer ve bilişsel yetenekler edinmeye başlamasıyla siyasal partiler gibi hiyerarşik otorite yapılarına olan güvenlerinin azalmasıdır (Bengtsson ve Mattila: 2009:1033). Bununla birlikte, sosyal modernleşmenin pek çok faktörü de bireylerin politik yeteneklerini ve ortalama vatandaşların bilgi ve erişim kaynaklarını çoğaltmıştır (Dalton vd., 2001:146). Başka bir deyişle, artan eğitim ve politik bilgiye daha kolay ulaşım gibi nedenlerle, yani "bilişsel hareketlilik" (Dalton, 1984: 264) dolayısıyla, bireylerin politik parti veya elitlere gerek kalmaksızın kendi kendine politik kararlar alabilme yetenekleri artmıştır (Dalton vd., 2001:146; Dalton, 2007:274; Bengtsson ve Mattila: 2009: 1033). Sonuç olarak da doğrudan demokrasi taleplerinde artış görülmüştür. Bu yaklaşıma göre daha iyi eğitimli, politik olarak ilgili ve bilgili ve de genç bireylerin doğrudan demokrasiyi daha yüksek oranda talep etmeleri beklenmektedir.

Politike Memnuniyetsiz̨lik açılamasına göre ise, mevcut temsili demokrasinin mekanizma ve kurumlarından memnuniyetsiz; kendini karar alma mekanizmalarından ve diğer politik süreçlerden dişlanmış hisseden bireyler de farklı bir politik sistem yaratma ve dolayısıly da doğrudan demokrasi talebinde bulunmaktadırlar (Dalton vd., 2001: 146). Buna göre, doğrudan demokrasiye yönelik artan talebin asıl nedenleri artan "politik sinizm" veya geleneksel demokratik yapılara olan kamusal güven kaybıdır (Craig vd., 2001: 25). Ayrica en önemli nedenlerden biri de kendini siyasetin çevresinde gören ve çoğunlukla mevcut siyasete ve kurumlarına olan inancını yitirmiş insanların sayısındaki artıştır (Donovan ve Karp, 2006:671). Bu nedenle de doğrudan demokrasi talebinin daha çok azınlıklar ve protest partiler arasında yaygın olduğu savunulmaktadır. Dalton (2004) ve Klingemann (1999:1033) bu kişileri demokrasinin kendisiyle değil de özel bir formu olan mevcut temsili demokrasi formuyla ilgili sorunlar1 olan "memnuniyetsiz demokratlar" olarak adlandırmaktadır. Memnuniyetsiz demokratlar; çevre sorunları, çokkültürlülük, yeni sosyal norm ve yaşam tarzları seçimleri gibi hususların artması ile birlikte politik gündem ve konuların karmaşık, çok boyutlu ve akışkan bir yapı aldığını savunurlar. Bu nedenle de artık politik konulara; mevcut temsili demokrasinin aktör ve kurumları ile değil, doğrudan demokrasi temelli daha etkili politik iletişim ve hareket kanallarının yer aldığı mekanizmalarla odaklanılması gerektiğine inanmaktadirlar (ayrica bk. Webb, 2013).

Dalton'un çalışması, önerdiği bu iki tezin ne ölçüde artan doğrudan demokrasi talebini açıkladığının; kimlerin, daha doğrusu hangi özelliklere sahip bireylerin, — örn. eğitim düzeyi, politik ilgi vb. — doğrudan demokrasi talebinde bulunduklarının tespitine dair farklı ampirik sonuçlara ulaşan çok sayıda akademik çalışmayı tetiklemiştir (bk. Gilljam vd., 1998; Donovan ve Karp, 2006; Bowler vd., 2007). Dalton'un çalışması, aşağıda da belirtileceği gibi, gizli demokrasi görüşünün gelişimi üzerinde de etkili olmuştur. Özetle söylenebilir ki, demokrasi üzerine son y1llarda gelişen 
ampirik akademik literatür, daha önce de belirtildiği gibi, temsili demokrasinin bir kriz içinde olduğu, bu nedenle de pratikte artan oranda doğrudan katılım talebi olduğu yönünde sonuçlara varmıştır.

\section{Gizli Demokrasi: Ampirik Çalışmaların Eleştirisi Üzerinden Yine Ampirikten Türeyen Bir Demokrasi Görüşü}

Yukarıda kısaca özetlenmeye çalışılan temsili demokrasi krizi ve doğrudan demokrasi ilişkisi üzerine akademide oluşan yaygin görüş o denli baskın haldedir ki, bu görüşe zıt olarak geliştirilmiş perspektifler çok azdır. $\mathrm{Bu}$ zıt görüşlerden en dikkat çekenlerinden, en çok referans verilenlerinden ve en çok ön plana çıanlarından biri ise Hibbing ve Theiss-Morse tarafından geliştirilen gizli demokrasi anlayışıdır. İki akademisyenin ayrı ayrı ve birlikte gerçekleştirdikleri, gizli demokrasi anlayışının ilk formları olan, daha sonra ise kavramı iyice olgunlaştırdıkları çeşitli çalışmaları mevcuttur (bk. Theiss-Morse, 2001; Hibbing ve Theiss-Morse, 1995, 2001a, 2001b; Hibbing vd., 2009; Flanigan vd., 2015). İkilinin, gizli demokrasi anlayışının asıl olgun halini sundukları çalışmalarında (Hibbing ve Theiss-Morse, 2002) ise kendi demokrasi anlayışlarını; yukarıda kısaca özetlenmeye çalışılan akademik çalışmalardan özellikle ampirik olanların metotlarının, ulaştıkları sonuçların ve geliştirdikleri argümanların bir kısmı üzerine eleştirel bir perspektif temelinde kurmuşlardır. Yine kendi gerçekleştirdikleri ampirik bir çalışmanın sonuçlarından yola çıkarak da gizli demokrasinin temel unsur ve varsayımlarını ortaya koymuşlardır. Özetle ampirik eleştirisi ve ampirikten teoriye uzanan bir çabanın ürünü olan gizli demokrasi kavramı kısaca şu şekilde açıklanabilir.

Hibbing ve Theiss-Morse - çalışmalarının metodolojik özellikleri, kullanılan bilgi toplama yöntemleri vb. gibi bu makalenin konusunu aşan detayları bir kenara bırakılırsa — çalışmalarında, Amerika Birleşik Devletleri'nde (ABD) yaşayan vatandaşların şu konulardaki görüşlerini çeşitli bilgi toplama araçlarıyla ölçmeyi amaçlamışlardır: (liberal) temsili demokrasi üzerine kurulu mevcut Amerikan politik sistemi, siyasa oluşum süreci ve karar alma mekanizmaları. Amerikan vatandaşlarının mevcut sistem üzerine özellikle olumsuz düşüncelerinden ve de mevcut sistemin sorunlu yönlerini aşmaya yönelik alternatif olarak sundukları görüşlerinden yola çıkarak bir demokrasi "teorisi” geliştirmişlerdir. Gizli demokrasi olarak adlandırdıkları bu demokrasi anlayışı iki temel düşünce üzerine kuruludur. Bunlardan ilki, Amerikan halkının mevcut temsili demokrasi kurumlarından memnuniyetsiz olduğudur. Başka bir deyişle, yukarıda ikinci bölümde bahsedilen akademik çalışmalara paralel olarak, temsili demokrasi bir kriz içerisindedir. İkincisi ise, bu kez akademideki yaygın görüşe zıt olacak şekilde, temsili demokrasi krizinin aşılması, politik karar alma süreçlerine daha az doğrudan vatandaş katılımı, siyasa oluşturma sürecinde ise daha çok uzman görüşüne yer verme 
ile sağlanabilir. Gizli demokrasi anlayışının bu iki temel unsurunu ayrı ayrı inceleyelim.

Gizli demokrasinin ilk unsuru temsili demokrasinin kurumlarına yönelik eleştiri ve memnuniyetsizliktir. Hibbing ve Theiss-Morse çalışmalarının sonuçlarından yola çıarak, temsili demokrasinin bir kriz içerisinde olduğunu, veya daha hafif bir tabirle, bu demokrasi anlayışına karşı bir memnuniyetsizlik ve güvensizlik olduğunu kabul etmektedirler. Bu memnuniyetsizlik özellikle de ikilinin temsili demokrasinin "tartışma", "uzlaşma" ve "yavaşlık" etrafinda tanımladıkları süreçleri üzerinde yoğunlaşmaktadır. Buna göre, aslında Amerikan toplumunda yaşayan bireyler, temel politik ve ekonomik görüşler ve hedefler noktasinda hemfikirlerdir. Ayrışmaya ve çatışmaya yol açan şey politikacıların kendi kişisel çıkarlarını maksimize etme çabalarıdır (Hibbing ve Theiss-Morse, 2002:7). Bu durum da politik tartışmayı kişisel çıkarlara odaklar, temel hedeflerdeki uzlaşma özelde uzlaşmaya yol açmaz, bu da karar alma ve siyasa oluşturma sürecini yavaşlatır. Başka bir deyişle, temsili demokrasinin kurumlarına olan memnuniyetsizliğin asıl kaynağı siyasetçilere ve siyasi temsilcilere olan güvensizliktir. Çalışmanın sonuçlarına bakıldığında, politikacilar halk tarafindan ehemmiyetsiz, partizanlıkları nedeniyle kamu yararını göz ardı eden ve kararları kendi özel ve bencil çıkarları tarafindan çok fazla etkilenen kişiler olarak tanımlanmaktadırlar.

Hibbing ve Theiss-Morse'a göre eğer doğrudan demokrasi talebine olan desteğin bir sebebi varsa o da işte bu bahsedilen memnuniyetsizliktir. Yani kişiler sadece mevcut temsili demokrasinin iyileştirilmesi gerektiğini düşünürler (Bengtsson ve Mattila: 2009:1034), demokratik karar alma mekanizmalarına daha çok katılma arzusunda değillerdir. Daha açık bir ifadeyle, bireyler sistemin herhangi bir kusurlu yönünden dolayı değil, aslında siyasete olan ilgisizlikleri ve politik çatışmayı gereksiz görmelerinden dolayı politikadan uzaklaşırlar (Hibbing ve Theiss-Morse, 2002:7, 10). Bu da gizli demokrasinin ikinci unsurunu oluşturur. Buna göre, daha önce yukarıda da bahsedilen ampirik çalısmalardaki önyargının da etkisiyle, anket veya mülakatlarda bireylere doğrudan demokrasi dışında geçerli başkaca bir alternatif sunulmadığ için, sonuçlar analiz edildiğinde bireylerin doğrudan demokrasiyi talep ettikleri gibi bir izlenim ortaya çıkmaktadır (Hibbing ve Theiss-Morse, 2002:88).

Buna göre, bireyler politik karar alma mekanizmalarına daha fazla katılma veya karar alıcılara daha fazla girdi sunma isteğinde değillerdir. Bireyler, sürecin tüm detaylarını bilmeyi ve hatta bu süreçlerin kendilerine sürekli görünür olmasını da istemezler (Hibbing ve Theiss-Morse, 2002:2). Hibbing ve Theiss-Morse'un ortaya koydukları alternatif demokrasi anlayışının gizliliğig/görünmezliği de buradan gelir. Yani bireyler esasında demokrasiye karşı değillerdir; bir karar alma mekanizmasının varlığını ister, bunu bilir ve buna 
katılırlar. Aynı zamanda, karar alıcıların hesap verebilir olması gerektiğini düşünürler ve karar alıcılar üzerindeki kontrollerini de korumak isterler. Bu kontrol mekanizmasının varlığını devam ettirme isteğindeki en temel neden de bireylerin politikacıları kamu yararı pahasına kendi çıkarları peşinde koşan bencil kişiler olarak görmeleridir.

Bu nedenle bireyler, varlıklarından emin oldukları demokratik karar alma mekanizmasinın mevcudiyetini talep eder, ancak bu mekanizmanın yalnızca alışılmadık ve istisnai durumlar söz konusu olunca görünür ve başvurmaya hazır olmasını isterler. Başka bir deyişle, aslında vatandaşlar giz̧li bir demokrasi anlayışını talep etmektedirler. Bu demokrasi anlayışı, politik karar alma süreçlerinde daha az katılıma, daha az tartışmaya (müzakereye) ve daha az partizan çıkarlara yer verilmesi görüşü üzerine kuruludur. İstisnai olarak başvurulan karar alma mekanizması ve siyasa oluşturma süreçlerinde, politikacılara karşı yukarıda bahsedilen güvensizliğin de etkisiyle, kişisel bencil çıkarlardan arınmış politik ve ekonomik görüşlerin istişaresi temelinde daha çok etkililiğe (hızlı ve verimli çalışma) ve objektifliğe yer olmalıdır (Hibbing ve Theiss-Morse, 2002:88). Bu da her iki süreçte de (seçilmemiş) uzman görüşlerine ve iş adamlarına yer vererek gerçekleşir (Hibbing ve Theiss-Morse, 2002:88, 143). İş adamlarının özellikle ekonomik karar alma sürecinde etkili olmalarının tercih edilmesinin sebebi, onların yeterli mal varlıkları nedeniyle kişisel çıkarlarını daha az ön plana koyacaklarına olan inançtır. Her ne kadar siyasa oluşumu uzmanlara bırakılsa da, bu süreçte vatandaşların uzmanlar üzerindeki denetimi devam edecek, başka bir deyişle, şeffaflık ve hesap verilebilirlik mekanizmaları varlığını koruyacaktır. Bu çerçevede özetle; gizli olan demokratik bir karar alma mekanizmasının varlığını bilen, buna istisnai de olsa başvuran ve de siyasaların etkin, objektif ve kişisel çıkarlardan arındırılarak oluştuğuna inanan bireyler, mevcut temsili demokrasinin kusurlu yönlerini daha çok değil daha az politik katılım yoluyla bertaraf etmiş olacaklardır.

Özetle görülüyor ki, gizli demokrasi anlayışı temsili demokrasi krizi ve doğrudan demokrasi talebi üzerine akademideki mevcut yaygın görüşle kimi noktalarda paralel görüşler ortaya koyarken, kimi noktalarda da bu görüşten ayrılmaktadır. Paralel görüşlerden en göze çarpanı gizli demokrasinin de bir temsili demokrasi eleştirisi üzerine kurulu olduğudur. Özellikle Dalton'un yukarıda bahsedilen ikili açıklaması dikkate alındı̆̆ında, gizli demokrasinin politik memnuniyetsizlik açıklamasına daha yakın bir temsili demokrasi eleştirisi sunduğu savunulabilir. Çünkü gizli demokrasinin temsili demokrasi eleştirisinde; bireylerin değişen politik ilgi, bilgi ve tutumları üzerine odaklı yeni politika/bilişsel hareketlilik açıklamasından herhangi bir iz görmek mümkün değildir. Başka bir deyişle, gizli demokrasi anlayışı, politik sinizm veya geleneksel demokratik yapılara olan kamusal güven kaybı noktasında politik memnuniyetsizlik açıklamasıyla benzerlik gösterse de, açıklamanın 
ikinci boyutunu oluşturan ve kendini siyasetin çevresinde gören insanların politik tutumları üzerinden hiçbir açıklama yapmamaktadır.

Gizli demokrasi anlayışının yukarıda bahsedilen mevcut yaygın görüşlerden ayrrldığ1 en önemli nokta ise demokratik karar alma mekanizmaları ve siyasa oluşturma süreçlerine doğrudan katılımın daha az olması gerektiği yönündeki görüştür. Karar alma mekanizmalarında uzman görüşlerine ve iş adamlarına yer vermesi nedeniyle elitizm (bk. Michels, 1915; Mosca, 1939; Pareto, 1966) ve teknokrasi/ekspertokrasiden (bk. Landwehr, 2009) izler taşıyan gizli demokrasi çok da orijinal bir yaklaşım sunmaz. Ancak gizli demokrasiyi, elitist ve teknokratik perspektiflerden ayıran nokta uzman görüşüne yapilan vurgunun temellendirmesinde yatmaktadır. Elitist veya teknokratik perspektiflerin, politika yapma ve siyasa oluşturma işini belli bir zümreye bırakma düşüncesi, genellikle sıradan vatandaşların politik bilgi eksikliği, politika yapma anlamındaki yeteneksizlikleri ve deneyimsizlikleri ile açıklanır. Ayrıca bu tercih, politik hususların karmaşıklığ ve teknik bilgi gerektirmesi gibi düşüncelerle de temellendirilir. Gizli demokrasi yaklaşımı ise aksine sistemden memnuniyetsizliğin kaynağı olarak bireylerin yeteneksizliğini vb. değil, onların politikaya olan ilgisizliklerini ve politikacılara karşı olan güvensizliklerini görür (Hibbing ve Theiss-Morse, 2002:8). Gizli demokraside yer alan elitist temelli karar alma ve siyasa üretme süreci, sıradan vatandaşların değil, aksine yukarıda bahsedilen siyasetçilerin sahip olduğu olumsuz özellikler nedeniyledir.

\section{Sonuç: Gizli Demokrasi Üzerine Genel Bir Değerlendirme}

$\mathrm{Bu}$ çalışmada, gizli demokrasi anlayışı üzerine genel bir inceleme sunulmaya çalışılmıştır. Kısaca gizli demokrasi, akademideki yaygın görüşe paralel olacak şekilde, temsili demokrasinin bir kriz içerisinde olduğunu kabul eder. Ancak bu krizin doğrudan demokrasi talebinde artışa yol açtı̆̆ fikrine karşı çıkar. Ayrıca temsili demokrasi krizinin, siyasete doğrudan katılımın arttırılması yoluyla aşılabileceği yönündeki akademideki yaygın görüşün aksini savunur.

Akademik literatürde, yaklaşı olarak son elli yıldır, temsili demokrasinin bir kriz içerisinde olduğu görüşü hakimdir. Bu krizin nedenlerine yönelik pek çok teorik, normatif ve ampirik temelli açıklama mevcuttur. Bu çalışmada özel olarak, yeni politika/bilişsel hareketlilik ve politik memnuniyetsizlik açılamalarına yer verilmiştir. Hibbing ve Theiss-Morse tarafindan geliştirilen gizli demokrasi de özellikle politik memnuniyetsizlik anlayışına benzer argümanlar sunar. Ampirik bir çalışmanın sonuçlarından yola çıkan (ABD örneği) gizli demokrasi, temsili demokrasinin kurum ve aktörlerine yönelik bir memnuniyetsizlik olduğunu kabul eder. Bu çerçevede, temsili demokrasinin kusurlu yönleri olduğunu savunur ve temsili demokrasinin kurumlarının iyileştirilmesini önerir. Ancak bunu yaparken, yaygın akademik 
görüşten ayrılarak, bu iyileştirmenin politik süreçlere daha çok katılımı teşvik ederek yapılmaması gerektiğini savunur. Aksine gizli demokrasi; politik karar alma süreçlerine daha az doğrudan vatandaş katılımını ve siyasa oluşturma sürecinde daha çok uzman görüşüne yer vermeyi krizin çözümü olarak sunar.

Çalışmanın bu sonuç kısmında, gizli demokrasinin temel ve kısa bir eleştirisi sunulmaya çalışılacaktır. Burada amaç sunulacak eleştirel unsurların, bilgimiz dahilinde Türkçe akademik literatürde henüz üzerine yapılmış kapsamlı bir çalışma yer almayan gizli demokrasi üzerine yapılabilecek çalışmalar için bir temel oluşturmasıdır. Eleştirel değerlendirme, bu makalenin niteliği de dikkate alındığında, Hibbing ve Theiss-Morse'un çalışmasının ampirik ve metodolojik eleştirisi görece daha kısa tutularak yapılacaktır. Eleştiri; (i) gizli demokrasinin dikkate değer yönlerine, (ii) onun bir "kuram/yaklaşım" ya da çok da "orijinal" veya "yeni”" bir görüş olmadığıyla ilgili tartışmaya ve (iii) temel argümanlarının doğrudan demokrasi ve müzakereci demokrasi çerçevesinden eleştirel incelenmesine odaklanacaktır. Eleştiri; kapsayıclık ve farklılıklara sayg1 temelinde şekillenecek bir katılım eksenli müzakereci demokrasinin neden hala değerli bir alternatif olabileceği ile sonlandırılacaktır.

İlk olarak söylenebilir ki, gizli demokrasi anlayışı; temsili demokrasi ve doğrudan demokrasi arasındaki güncel ilişkiye dair yaygın görüşten farklı bir perspektif sunması açısından dikkate değerdir. Kavram, ortaya atıldığ dönemden beri, özellikle doğrudan demokrasi üzerine ampirik çalısmalar yapan pek çok akademisyenin çalışmalarında referans verdiği bir kavram halini almıştır. Aynı zamanda ABD dışındaki farklı örneklerde de benzer ampirik çalışmalar yapılmasının önünü açmıştır (bk. Bengtsson ve Mattila: 2009; Coffé ve Michels, 2014; Ruostetsaari, 2017). Gizli demokrasi, temsili demokrasi krizinin aşılmasına yönelik görüşleriyle doğrudan demokrasi anlayışı üzerine olan tartışmaları hem arttırmış hem de çeşitlendirmiştir. Aristocu ve Arendtçi bakış açılarının, iyi bir hayatın ancak siyasete aktif katılımla gerçekleşeceğine yönelik vurgularına karşın, politik ilgisizlik unsurunu bir kez daha ön plana çıkarmıştır. Esas amacı bu olmasa da; siyasete katılımın, bireyi mutluluğa götürecek diğer eylemler arasında her zaman ve koşulsuz bir önceliği olamayacağ1 yönündeki liberteryen görüşlerin yeniden gündeme gelmesini de sağlamıştır. Gizli demokrasi, özellikle Batı toplumlarındaki düşük kattlım ve "politikadan uzak durma arzusuna" (Hibbing ve Theiss-Morse, 2002:3, 134) yönelik de bir görüss sunmas1 açısından dikkate değerdir. Başka bir deyişle, gizli demokrasi hem mevcut sistem ve politikadan memnuniyetsiz, hem de ayn zamanda politik katılimı istemeyenler üzerine bir görüş ortaya koymuştur (Hibbing ve Theiss-Morse, 2002:3). Ayn1 zamanda kavram, popülizm nedeniyle anti-demokratik kararların demokratik yolla alınması tartısmalarını beslemesi açısından da önemlidir. Gizli demokrasiyi dikkate değer yapan bir başka unsur da küresel 
1sınma, klonlama çalışmaları vb. gibi sıradan vatandaşların politika tercihlerine birakılamayacak kadar karmaşık ve çok boyutlu olan konularda uzman görüşünün karar alma sürecindeki kaçınılmaz rolüne yönelik tartışmaları canlandırmasıdır.

Sayılan tüm bu dikkate değer yönlerine rağmen gizli demokrasi anlayışının olumsuz eleştiriye açık tarafları da mevcuttur. Öncelikle genel olarak söylenebilir ki; tarihin belirli bir döneminde, belirli özelliklere ve belirli siyasal tutumlara haiz bir toplumdaki bireylerin görüşlerine dayanarak yapılan ampirik bir çalışmanın sonuçlarından yola çıkarak genel-geçer bir teorik (ve hatta normatif) demokrasi anlayışı üretmek eleştiriye açıktır. Başka bir deyişle, ABD'de yapılan, ulusal kamuoyu araştırması ve odak grup çalışmalarından elde edilen bulgulara dayalı bir durum tespitinden yola çıkarak bir demokrasi anlayışı veya kuramına ulaşmak sorunlu ve tartışmalıdır. Bu yorum; kurumsalcı, ampirik ve tanımlayıcı çalışmaların ya da olumsallık ve izlek bağımlılığ1 gibi perspektiflerin sosyal bilimlerdeki rolünü yadsımak anlamına gelmez. Denebilir ki, belirli bir ampirik örnekten yola çıkılarak ulaşılan teorik varsayım ve sonuçların geçerliliği ve kabul edilebilirliği; normatif ve teorik temelli çalışmalarınkinden daha zayıf olabilir. Zaten Amerikan toplumu dişında, ancak bu toplumla benzer politik, ekonomik ve sosyal yapılar gösteren, diğer modern (liberal) demokratik toplumlarda gerçekleştirilen ampirik çalışmalarda, gizli demokrasiye yönelik farklı ve bazen Amerikan örneği ile taban tabana zıt yaklaşımlar ve eğilimler ortaya çıkmıştır (bk. Bengtsson ve Mattila: 2009; Webb, 2013; Coffé ve Michels, 2014; Ruostetsaari, 2017). Hibbing ve Theiss-Morse'un da kitaplarında bahsedilen bu soruna dikkat çektikleri görülür. İkili, gizli demokrasinin ancak tutarlı teorik ve normatif argümanlarla temellendirildiğinde gerçek bir demokrasi kuramına dönüşebileceğini düşünmektedirler (Hibbing ve Theiss-Morse, 2002:9-11). İşte tam da bu nedenlerle bu çalışmanın başlığında gizli demokrasi için teori veya yaklaşım yerine "görüş" ibaresi kullanılmış ve aynı bakış açısı çalışmanın diğer kısımlarında da sürdürülmüştür.

Gizli demokrasiyi bir kuram ya da yaklaşımdan çok görüş olarak nitelendirmekteki bir diğer neden de aslında onun argümanlarının ve temel unsurlarının çok da "yeni” veya "orijinal” olmadığıdır. Daha önce de belirtildiği gibi, aslında gizli demokrasi elitist perspektiflerden bir noktada ayrılır. Bu nokta, gizli demokrasinin, uzman görüşüne olan ihtiyac1, bireylerin politikaya olan ilgisizlikleri ve politikacılara karşı olan güvensizlikleri üzerinden temellendirmesidir. Bu farka rağmen özünde gizli demokrasi yine de Mosca, Michels ve Paretocu elitist perspektiflerin ve teknokrasi/ekspertokrasinin argümanlarının bir tekrarı niteliğindedir. Aynı zamanda, sıradan insanların siyasetle ilgilenmedikleri tespiti de halihazırda zaten Joseph A. Schumpeter gibi günümüz temsil demokrasisini "rekabetçi elitizm" olarak niteleyen birçok siyaset kuramcısı tarafından dile getirilmiştir 
(bk. Schumpeter, 1973; Best ve Highley, 2010). Ayrica siradan insanların siyasete ilgisizliğini verili kabul ederek formüle edilecek bir politika modelinin neden yanlış ve sorunlu olduğu konusuna da 1960’lardan itibaren, özellikle John Dewey'e ve daha sonra da Carole Pateman'in katilımc1 demokrasi yaklaşımına odaklanarak, birçok demokrasi kuramcısı tarafindan açıklama getirilmiştir (bk. Pateman, 1970, 2012; Dewey, 1997; Honneth, 1998; Caspary, 2000, Goatcher, 2005). Bir başka husus da gizli demokrasinin argümanlarının, bilhassa neoliberal ekonomi politikalarının zirve yaptığ1 1970'lerin sonundan günümüze kadar olan dönemdeki teknokratik yönetim anlayışlarında benzer bir ifadesini bulmasıdır. Bir görüşe göre, Keynesyen ekonomi politikalarının etkisiyle, 1980'lere kadar devletin ekonomiye artan orandaki müdahalesi ve refah devleti anlayışı; siyasete aktif katıllım ve seçmen taleplerinde artışa yol açmıştır. Bunu, yani temelde seçmen katıllımını azaltmak amacıyla da devlet, özellikle demokratikleşme sürecindeki gelişmekte olan ülkelerde, yönetişim kavramı ve (bağımsız) üst kurullar aracılı̆̆ılya ekonominin teknokratik biçimde yönetilmesine yönelmiş̧ir (bk. Ataay, 2007; Ataay, 2018; Kiely, 2016; Silva, 2018). Bu durum da demokrasi ve teknokrasi arasındaki ilişkinin tıpkı gizli demokrasideki gibi benzer bir biçim almasına yol açmışır. Son olarak, ve belki de kavramın orijinalliği veya yeniliği konusundaki en önemli noktalardan biri, gizli demokrasinin esas argümanlarından biri olan siyasete katılımın azaltılması, yurttaşların ancak gerekli olduğu zaman, memnuniyetsizliklerini belirtmek ve denetlemek amacıyla siyasete katılması önerisi de "yeni" değildir. Bire bir olmasa da benzer bir öneri, "poliarşi" kavramının yaratıcısı ve bir politik sistemin demokrasi olarak nitelendirilebilmesi için gerekli asgari şartları sıralayan ünlü demokrasi kuramcılarından Robert Dahl'dan gelmiştir. Dahl, "esnek güç" kavramı üzerinden aslında her bireyin birer "homo politicus" olmadığını, yani politikaya katılım noktasında isteksiz ve hareketsiz kalabileceğini belirtmiştir. Dahl'a göre bazı bireyler politikaya ancak gerekli gördüklerinde, yani hükümetin amaçlarından memnun değilseler, ve de daha üst seviyeden (örn. elit siyaseti takip etme gibi) katılmay1 tercih edebilirler (bk. Dahl, 2005; Buechler, 2016). Kisaca demokrasi literatürü bize, gizli demokrasinin ana unsur ve varsayımlarının çok da yeni veya alternatif olmadığını göstermektedir.

Öte yandan, gizli demokraside yer alan, demokratik karar alma ve siyasa oluşturma süreçlerinde daha çok uzman görüşüne ve iş adamlarına yer verilmesi düşüncesi şu iki husus için önem arz edebilir: popülizmin yaratabileceği çoğunluk despotizmi ile mücadele ve karmaşı teknik konularda uzman görüşü gerekliliği. Ancak aynı husus; topyekun siyaseti, (agonistik) çatışma ve değer yargılarından arındırılmış, teknik bir aktiviteye dönüştürme riski de taşır. Her ne kadar gizli demokrasi aksini iddia etse de, en temel politik, etik, ekonomik değer ve hedefler veya bu hedeflere nasıl ulaşılacağı noktasında en homojen görünen toplumda yaşayan bireyler 
arasında bile fikir ayrllıkları mevcuttur. Her toplum, özellikle de ABD gibi liberal demokratik toplumlar, birbiriyle uzlaşamaz görünen, rekabet halindeki değer ve dünya görüşlerini bir arada barındırır. Günümüz çağdaş toplumları ise özellikle küreselleşme ile birlikte çokkültürlü bir yap1 arz etmeye başlamışlardır. Siyaset de, farklılıkların yarattığ (agonistik) çatışmanın tartışma ve uzlaşı yoluyla çözülmesi demektir. Bu uzlaşı sürecinde, elitlerin ve uzmanlarınki de dahil olmak üzere, ortaya atılan hiçbir politik argüman salt ampirik ve bilimsel temellere dayanmaz; ister istemez değer yargılarını yansitır. Bonotti'nin $(2011: 117,119)$ de belirttiği gibi "eğer her zaman ampirik olarak test edilip yanlışlanabilir temeller üzerine politik kararlar alabilseydik, zaten politikaya ihtiyacımız kalma[zdı]". Bununla beraber, gizli demokrasinin varsayımının aksine, siyasetin her basamağında aktif rol oynayacak elitlerin/uzmanların her zaman objektif hareket edeceği, etkili çalışacağ1 ve bireysel çıkarlarından sıyrılarak kamu yararını gözeten kararlar alacağı ne tam olarak bilinebilir ne de garanti edilebilir. İşin daha riskli olan tarafi ise, zamanla oluşabilecek bir otoriter/totaliter elit/teknokrat yönetimidir. Bu tür bir riski, mevcut temsili demokraside de yer alan ve gizli demokrasinin de önerdiği, şeffaflık ve hesap verilebilirlik gibi araçlarla önlemek kolay değildir.

Gizli demokrasinin doğrudan katılıma yönelik olumsuz tutumu (Hibbing ve Theiss-Morse, 2002: 5, 207) ise karar alma sürecine doğrudan kattlımın ve onun muhtemel sonuçlarından biri olan müzakerenin değerini ve önemini ortadan kaldırmaz. Temsili demokrasi krizinin aşılması ve normatif açıdan daha değerli bir demokrasi anlayışına ulaşma noktasında doğrudan katılım ve müzakerenin yeri önemlidir. Günümüzde popülizm, otoriter yönetim anlayışları, aşırı sağ ve yabancı düşmanlığ gibi durumlar, başta Batı demokrasilerinde olmak üzere tüm dünyada yükselme eğilimindedir. $\mathrm{Bu}$ durum, artık demokrasinin tek bir formunun değil, katılımcı formu başta olmak üzere topyekun kendisinin bir kriz yaşadığı yorumlarına yol açmıştır. Başka bir deyişle, insan haklarıyla beraber demokrasinin bir "düşüşte" olduğu ve karar alma süreçlerinde elitist vurgunun ön plana çıtı̆ğ1 yorumları yaygınlaşmışır (bk. Diamond ve Plattner, 2015; Kekic, 2017; Öniş, 2017; Beyme, 2018). Bu eğilimin tersine döndürülmesi için, gizli demokrasi gibi daha az katılımc1 ve elitist yorumlara karşın doğrudan ve müzakereci demokrasi anlayışlarının temel teorik ve normatif unsurları yeniden değerlendirilebilir ve ön plana ç1karılabilir. Çünkü gizli demokrasi; hem doğrudan katılım veya müzakereye eleştirel elitist bir perspektif sunar hem de ironik bir şekilde doğrudan demokrasiye yönelik bir talepleri olması bakımından da popülist perspektiften izler taşır (bk. Webb, 2013).

Doğrudan katılım eksenli bir müzakereci demokrasi yaklaşımı; birbiriyle uzlaşamaz görünen, rekabet halindeki değer, iyi hayat anlayışları ve dünya görüşlerini bir arada barındıran toplumlar için değerli bir alternatiftir. Çünkü bu yaklaşım; farklılıklara saygılı bir siyasetin ve karar alma sürecinin 
meşruiyet ve etkililiğini arttırmada önemli rol oynar. Bu demokrasi anlayışı, çalışmanın başından beri bahsedilen temsili demokrasi krizinin çözümüne yönelik halen en önemli alternatiflerden birisidir. Gizli demokrasi, özellikle kendini siyasetin çevresinde gören ve çoğunlukla mevcut siyasete, onun kurumlarına olan inancını yitirmiş insanların dışlanmaları ve bu kişilerin siyasete hangi kanallarla entegre olacakları konusunda hiçbir açılama yapmamaktadır. Bununla beraber, çokkültürlülük ve farklılıkların bir arada yaşaması üzerine şekillenen postmodern toplumlardaki siyaset tartışmalarıyla ilgili olarak da herhangi yeni bir şey söylememektedir. Başka bir deyişle, bir arada yaşamanın yeni formülleri, siyasetin farklılaşan yeni yolları veya araçları üzerine süregelen güncel siyaset tartşmalarına hiçbir yeni boyut kazandıramamaktadır. Aksine gizli demokrasi; teorik ve normatif değer ve görüşlerden uzak, sadece politikacıların ehemmiyetsizliği ve çıkarcilığ görüşüne dayalı, mevcut sistemin yavaşlığ temelinde şekillenen teknik, sığ ve konjonktürel bir açıklama sunmaktadır.

Oysa doğrudan katılım ve müzakere eksenli, farkl1liklara saygllı ve kapsayıc1 bir karar alma ve siyasa oluşturma süreci ile (i) "memnuniyetsiz demokratlar" da dahil olmak üzere herkese bu süreçlere daha eşit katılım hakk1 verilebilir; bu yolla (ii) demokrasinin eşit katılım ve devlet tarafsızlığ gibi ideallerinin daha iyi gerçekleştirilebilmesi sağlanabilir, ve (iii) farklılıklarla bir arada barış içerisinde yaşayabilmek için bireylerin tutum, davranış ve perspektiflerinde eğitim aracilığyla gerçekleştirilebilecek dönüşümde ilerleme sağlanabilir. Bu da, temsili demokrasi krizinin aşılması için, bahsedilen tarzda bir "katıllimc1 demokratik" perspektifi benimsemeyi, gizli demokrasi gibi "daha az demokratik" bir perspektifi benimsemekten daha değerli bir alternatif haline getirebilir. 


\section{Kaynaklar}

ALONSO, S., KEANE, J. ve MERKEL, W. Der. (2011) The Future of Representative Democracy, Cambridge University Press, Cambridge.

ALTMAN, D. (2011) Direct Democracy Worldwide, Cambridge University Press, New York.

ATAAY, F. (2007) Neoliberalizm, Kamu Reformu, Demokrasi, AKSOY, Ş. ve ÜSTÜNER, Y. (der.) Kamu Yönetimi: Kuram ve Uygulama içinde, Nobel Yayıncilik, Ankara, 163-172.

ATAAY, F. (2018) Neoliberalizm, Düzenleyici Devlet ve Yönetişim, ERAT, V. vd. (der.) Qou Vadis: Kamu Yönetimi içinde, Nika Yayınevi, Ankara, 275-293.

BARBER, B. R. (1984) Strong Democracy: Participatory Politics for A New Age, University of California Press, Berkeley, CA.

BENGTSSON, A. ve MATTILA, M. (2009) Direct democracy and its critics: support for direct democracy and "stealth" democracy in finland, West European Politics, 32 (5), 1031-1048.

BEST, H. ve HIGHLEY, J. (2010) Democratic Elitism: New Theoretical and Comparative Perspectives, Brill, UK.

BUTLER D. ve RANNEY A. Der. (1994) Referendums Around the World: The Growing Use of Direct Democracy, The AEI Press, Washington.

BOHMAN, J. (1998) Survey article: the coming of age of deliberative democracy (1998), The Journal of Political Philosophy, 6 (4), 400-425.

BONOTTI, M. (2011) Religious political parties and the limits of political liberalism, Res Publica, 17(2), 107-123.

BOWLER, S. DONOVAN, T. ve KARP, J. A. (2007) Enraged or engaged? Preferences for direct citizen participation in affluent democracies, Political Research Quarterly, 60 (3), 351-362.

BUECHLER, S. (2016) Critical Sociology, İkinci bask1, Routledge, New York.

CASPARY, W. R. (2000) Dewey on Democracy, Cornell University Press, New York.

CHAMBERS, S. (2003) Deliberative democratic theory, Annual Review of Political Science, 6, 307-326.

COFFÉ, H. ve MICHELS, A. (2014) Education and support for representative, direct and stealth democracy, Electoral Studies, 35, 111. 
COOKE, M. (2017) Five arguments for deliberative democracy, D'ENTREVES, M. (der.) Democracy as Public Deliberation içinde, Routledge, Oxon ve New York, 53-87.

CRAIG, S., KREPPEL, A. ve KANE, J. (2001) Public opinion and support for direct democracy: a grassroots perspective, MENDELSOHN, M. ve PARKIN, A. (der.) Referendum Democracy: Citizens, Elites and Deliberation in Referendum Campaigns içinde, Palgrave, New York, 2546.

DAHL, R. (2005) Who Governs: Democracy and Power in an American City, Yale University Press, New Haven.

DALTON, R. J. (1984) Cognitive mobilization and partisan dealignment in advanced industrial democracies, Journal of Politics , 46(1), 264-284.

DALTON, R. J. (2004) Democratic Challenges, Democratic Choices The Erosion Of Political Support in Advanced Democracies, Oxford University Press, New York.

DALTON, R. J. (2007) Partisan mobilization, cognitive mobilization and the changing american electorate, Electoral Studies, 26 (2), 274-286.

DALTON, R. J. (2008) Citizen Politics: Public Opinion And Political Parties in Advanced Industrial Democracies, CQ Press, Washington DC.

DALTON, R. J., BURKLIN, W. P., ve DRUMMOND, A. (2001) Public opinion and direct democracy, Journal of Democracy, 12(4), 141-153.

DALTON, R. J. ve SCARROW, S. E. Der. (2003) Democracy Transformed? Expanding Political Opportunities in Advanced Industrial Democracies, Oxford University Press, New York.

DENNIS, J. ve OWEN, D. (2001) Popular satisfaction with the party system and representative democracy in the united states, International Political Science Review, 22 (4), 399-415.

DEWEY, J. (1997) Democracy and Education, Dover Publications, New York.

DIAMOND, L. ve PLAT'TNER, M. F. Der. (2015) Democracy in Decline?, Johns Hopkins University Press, Maryland.

DONOVAN, T. ve KARP, J. A. (2006) Popular support for direct democracy, Party Politics, 12 (5), 671-688.

DRYZEK, J. S. (1990) Discursive Democracy: Politics, Policy and Political Science, Cambridge University Press, Cambridge.

FISHKIN, J. (1991) Democracy and Deliberation: New Directions for Democratic Reform, Yale University Press, New York. 
FLANIGAN, W., ZINGALE, N., THEISS-MORSE, E., ve WAGNER, M. W. (2015) Political Behavior of the American Electorate, 13. Bask1, CQ Press, Washington, DC.

GALLAGHER, M. ve ULERI, P. U. (1996) The Referendum Experience in Europe, MacMillan Press, London.

GERRET, E. (1997) Who directs direct democracy, University of Chicago Law School Roundtable, 4 (1), 17-36.

GHERGHINA, S. (2017) Direct democracy and subjective regime legitimacy in europe, Democratization, 24(4), 613-631.

GILLJAM, M., PESONEN, P. ve LISTHAUG, O. (1998) The referendum in representative democracies, JENSSEN, A. T., PESONEN, P. ve GILLJAM, M. (der.), To Join or Not to Join: Three Nordic Referendums on Membership in the European Union içinde, Scandinavian University Press, Oslo.

GOATCHER, J. (2005). Carole pateman and the nature of participatory democracy, Contemporary Politics, 11(4), 217-234.

GRAY, M. ve CAUL, M. (2000) Declining voter turnout in advanced industrial democracies, 1950 to 1997: the effects of declining group mobilization, Comparative Political Studies, 1091-1122.

HARTZ-KARP, J. ve BRIAND, M. K. (2009) Institutionalising deliberative democracy: theoretical and practical challenges, Australasian Parliamentary Review, 24 (1), 167-198.

HABERMAS, J. (1996) Between Facts and Norms: Contributions to a Discourse Theory of Law and Democracy, çev. William Rehg, The MIT Press, Massachusetts.

HIBBING, J. R. ve THEISS-MORSE, E. (1995)Congress as Public Enemy: Public Attitudes toward American Political Institutions, Cambridge: Cambridge University Press, New York.

HIBBING, J. R. ve THEISS-MORSE, E. (2001a) Process preferences and american politics: what the people want government to be, American Political Science Review, 95, 145-153.

HIBBING, J. R. ve THEISS-MORSE, E. Der. (2001b) What Is It About Government That Americans Dislike?, Cambridge: Cambridge University Press, New York.

HIBBING, J. R. ve THEISS-MORSE, E. (2002) Stealth Democracy: Americans' Beliefs About How Government Should Work, Cambridge University Press, Cambridge. 
HIBBING, J. R. ve THEISS-MORSE, E. ve WHITAKER, E. (2009) Americans' perceptions of the nature of governing, MONDAK,J. J. ve MITCHELL, D. (der.), Fault Lines: Why the Republicans Lost Congress içinde, Routledge, New York, 148-165.

HONNETH, A. (1998) Democracy as reflexive cooperation: john dewey and the theory of democracy today, Political Theory, 26 (6), 763-783.

INGLEHART, R. (1977) Silent Revolution: Changing Values and Political Styles Among Western Publics, Princeton University Press, Princeton.

INGLEHART, R. (1990) Culture Shift in Advanced Industrial Society, Princeton University Press, Princeton.

INGLEHART, R. VE WELZEL, C. (2005) Modernization, cultural change and democracy: The human development sequence, Cambridge University Press, Cambridge.

INVERNIZZI-ACCET'TI, C. ve WOLKENSTEIN, F. (2017) The crisis of party democracy, cognitive mobilization, and the case for making parties more deliberative, American Political Science Review, 111(1), 97109.

KEKIC, L. (2017) The economist intelligence unit's index of democracy, https://www.economist.com/media/pdf/DEMOCRACY_INDE X_2007_v3.pdf, erişim tarihi 26 Mayıs 2018.

KIELY, R. (2016) From authoritarian liberalism to economic technocracy: neoliberalism, politics and "de-democratization", Critical Sociology, 43 (4), 725-745.

KLINGEMANN, H. (1999) Mapping political support in the 1990s: a global analysis, NORRIS, P. (der.), Critical Citizens: Global Support for Democratic Governance içinde, Oxford University Press, New York.

KNOPFF, R. (1998) Populism and the politics of rights: the dual attack on representative democracy, Canadian Journal of Political Science, 31 (4), 683-705.

LANDWEHR, C. (2004) Democratic and technocratic policy deliberation, Critical Policy Studies, 3(3-4), 434-439.

MICHELS, R. (1968) Political Parties, ilk basim 1915, Free Press, New York.

MOREL, L. ve QVORTRUP, M. (2017) The Routledge Handbook to Referendums and Direct Democracy Routledge, Londra, https://www.routledgehandbooks.com/doi/10.4324/9780203713 181-4, erişim tarihi 26 Mayıs 2018.

MOSCA, G. (1939) The Ruling Class, Mc-Graw-Hill, New York. 
NORRIS, P. Der.(1999) Critical Citizens: Global Support For Democratic Governance, Oxford University Press, New York.

ÖNISS, Z. (2017) The age of anxiety: the crisis of liberal democracy in a post-hegemonic global order, The International Spectator Italian Journal of International Spectator, 52 (3), 18-35.

PARETO, V. (1976) Sociological Writings, Rowman and Littlefield, New Jersey.

PATEMAN, C. (1970), Participation and Democratic Theory, Cambridge University Press, Cambridge.

PATEMAN, C. (2012) Participatory democracy revisited, Perspectives on Politics, 10 (1), 7-19.

PHARR, S. J., PUTNAM R. D., ve DALTON, R. J. (2000) Trouble in the advanced democracies? a quarter-century of declining confidence, Journal of Democracy, 11 (2), 5-25.

PITKIN, H. F. (2004) Representation and democracy: uneasy alliance, Scandinavian Political Studies, 27 (3), 335-342.

RUOSTETSAARI, I. (2017) Stealth democracy, elitism, and citizenship in finnish energy policy, Energy Research \& Social Science, 34, 93-103.

SAWARD, M. (2003) Democracy, Polity Press, Cornwall.

SILVA, P. (2018) Neoliberalism, democratization, and the rise of technocrats, VELLINGA, M. The Changing Role of the State in Latin America içinde, Routledge, New York, 75-92.

THEISS-MORSE, E.(2002)The perils of voice and the desire for stealth democracy, Maine Policy Review, 11, 80-89.

SCHUMPETER, J. A. (1976) Capitalism, Socialism and Democracy, revize bask1, Routledge, ABD.

SMITH, G. ve WALES, C. (2000) Citizens' juries and deliberative democracy, Political Studies, 48 (1), 51-65.

VON BEYME, K. (2018) From Post-Democracy to Neo-Democracy, Springer, Cham.

WEALE, A. (2007), Democracy, ikinci bask1, Palgrave Macmillan, New York.

WEBB, P. (2013) Who is willing to participate? dissatisfied democrats, stealth democrats and populists in the united kingdom, European Journal of Political Research, 52 (6), 747-772. 